\title{
Chromosomes of Asian cyprinid fishes: cytogenetic analysis of two representatives of small paleotetraploid tribe Probarbini
}

\author{
Pasakorn Saenjundaeng ${ }^{1}$, Marcelo de Bello Cioffi ${ }^{2 *}$, Ezequiel Aguiar de Oliveira ${ }^{2,3}$, Alongklod Tanomtong ${ }^{1}$, \\ Weerayuth Supiwong ${ }^{4}$, Sumalee Phimphan ${ }^{1}$, Maria João Collares-Pereira ${ }^{5}$, Alexandr Sember ${ }^{6}$, \\ Luiz Antonio Carlos Bertollo², Thomas Liehr ${ }^{7}$, Cassia Fernanda Yano², Terumi Hatanaka² and Petr Ráb ${ }^{6}$
}

\begin{abstract}
Background: Polyploidy, although still poorly explored, represents an important evolutionary event in several cyprinid clades. Herein, Catlocarpio siamensis and Probarbus jullieni - representatives of the paleotetraploid tribe Probarbini, were characterized both by conventional and molecular cytogenetic methods.

Results: Alike most other paleotetraploid cyprinids (with $2 n=100$ ), both species studied here shared $2 n=98$ but differed in karyotypes: C. siamensis displayed 18m + 34sm + 46st/a; NF = 150, while P. jullieni exhibited 26m + 14sm + 58st/a; NF = 138. Fluorescence in situ hybridization (FISH) with rDNA probes revealed two (5S) and eight (18S) signals in C. siamensis, respectively, and six signals for both probes in P. jullieni. FISH with microsatellite motifs evidenced substantial genomic divergence between both species. The almost doubled size of the chromosome pairs \#1 in C. siamensis and \#14 in $P$. jullieni compared to the rest of corresponding karyotypes indicated chromosomal fusions.

Conclusion: Based on our findings, together with likely the same reduced $2 n=98$ karyotypes in the remainder Probarbini species, we hypothesize that the karyotype $2 n=98$ might represent a derived character, shared by all members of the Probarbini clade. Besides, we also witnessed considerable changes in the amount and distribution of certain repetitive DNA classes, suggesting complex post-polyploidization processes in this small paleotetraploid tribe.
\end{abstract}

Keywords: Fish cytogenetics, Cyprinidae, Chromosomal markers, rDNAs, Microsatellites

\section{Background}

One of the most important evolutionary characteristics of Teleostei is a lineage-specific polyploidization (i.e. teleost-specific whole-genome duplication $=$ TS-WGD) that occurred approximately 226-316 Mya [1], subsequently to its divergence from the remaining actinopterygians (i.e. bichirs, sturgeons, paddlefishes, gars and bowfin) $[2,3]$. Furthermore, additional whole-genome duplications (WGDs) took place independently in several other teleostean lineages, such as, e.g., Catostomidae [4], Cobitidae [5], Callichthyidae [6, 7], Salmoniformes [8] and especially Cyprinidae [9-11].

\footnotetext{
* Correspondence: mbcioffi@ufscar.br

${ }^{2}$ Departamento de Genética e Evolução, Universidade Federal de São Carlos,

São Carlos, SP, Brazil

Full list of author information is available at the end of the article
}

Independent evolutionary tetraploidy and even recurrent hexaploid events of allopolyploid origin have already been evidenced for several cyprinid clades taxonomically recognized as tribes [9]; these are Probarbini, Torini, Smiliogastrini, Cyprinini, Spinibarbini, Schizothoracini, Schizopygopsini and Barbini and overall account for more than 400 polyploid species. Probarbini represents the most early-diverging group [9], with only two genera: (i) the monotypic Catlocarpio (C. siamensis Boulenger, 1898) being the largest known cyprinid species attaining a length of up to three meters [12, 13], and (ii) the genus Probarbus, with three valid species [14] (P. jullieni Sauvage, 1880, P. labeamajor Roberts, 1992 and P. labeaminor Roberts, 1992). These four potamodromous species from large river systems in Southeast Asia have been and are heavily declining in the sizes of populations due to fishery pressures, but also due to

(c) The Author(s). 2018 Open Access This article is distributed under the terms of the Creative Commons Attribution 4.0 International License (http://creativecommons.org/licenses/by/4.0/), which permits unrestricted use, distribution, and 
habitat loss and degradation. Thus, since extirpated from most of their native range, these species were considered as "threatened" following IUCN criteria (IUCN Red List of Threatened Species 2012) [15-18].

Irrespective of the evolutionary importance of paleopolyploidy present in various clades of cyprinid fishes [9], its cytogenetic investigation remains practically restricted to reports about diploid chromosome numbers (2n) and karyotype descriptions, rarely complemented with particular chromosome banding protocols [19]. Even less studies applied molecular cytogenetic approaches, such as e.g. the physical mapping of ribosomal genes in Indian species of the genus Tor, tribe Torini $[20,21]$. The $2 \mathrm{n}$ and the karyotypes of the species studied herein were previously reported based exclusively on conventionally Giemsa-stained chromosomes [22, 23]. Based on those reports, two individuals of $P$. jullieni and C. siamensis, obtained from aquarium fish dealer, possessed $2 \mathrm{n}=98$ chromosomes, differing in the proportion of chromosome categories: $(18 \mathrm{~m}+54 \mathrm{sm} / \mathrm{st}+26 \mathrm{a})$ in $P$. jullieni and $(18 \mathrm{~m}+28 \mathrm{sm} / \mathrm{st}+52 \mathrm{a})$ in C. siamensis. The present study includes in depth cytogenetic analyses of these two species, comprising conventional Giemsa-staining, $\mathrm{C}$-banding and fluorescence in situ hybridization (FISH) approaches with chromosomal mapping of several repetitive DNA classes.

\section{Results}

\section{Karyotypes}

C. siamensis possesses $2 \mathrm{n}=98$ with the karyotype composed of $18 m+34 s m+46 s t / a$ elements, with number of chromosomal arms (NF, Nombre Fondamental) being equal to 150. $P$. jullieni shares with the former species $2 \mathrm{n}=98$, but differs in karyotype composition having $26 \mathrm{~m}+14 \mathrm{sm}+58 \mathrm{st} / \mathrm{a}$ and $\mathrm{NF}=138$. The chromosome pairs $\# 1$ in C. siamensis and \#14 in P. jullieni were almost doubled in size when compared to the rest of corresponding karyotypes. No differences between male and female karyotypes occur in both species (Fig. 1).

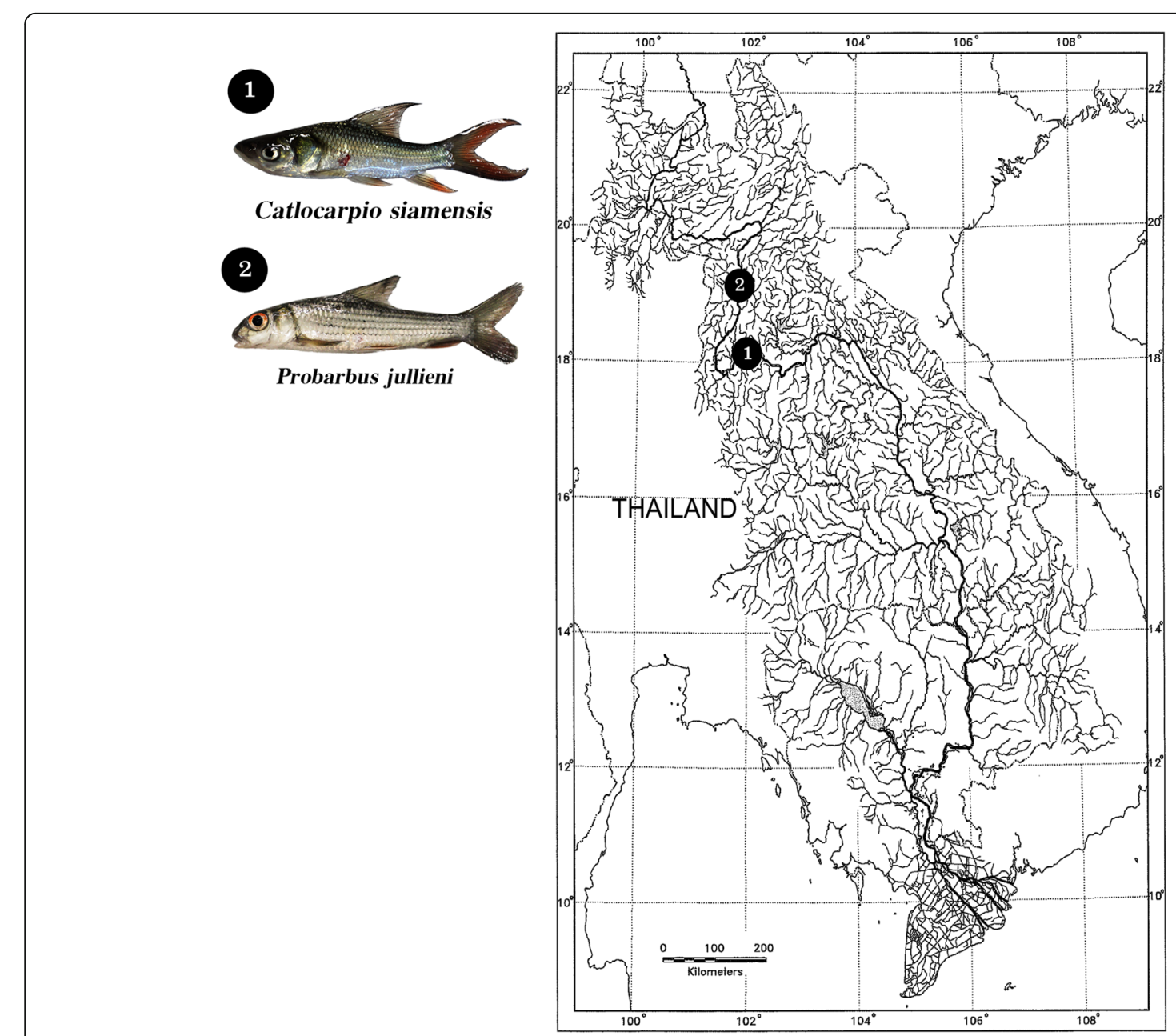

Fig. 1 Collection sites of Catlocarpio siamensis and Probarbus jullieni in Thailand examined in the present study (Map of the Mekong River basin modified from Rainboth [13]) 


\section{Chromosome mapping of $5 \mathrm{~S}$ and $18 \mathrm{~S}$ ribosomal DNA (rDNA) sequences}

In the genome of $C$. siamensis, the minor $5 \mathrm{~S}$ rDNA class is located on a single chromosomal pair (\#27), while the major 18S rDNA occurs in four chromosome pairs (\#22, \#23, \#40, \#41). By contrast, in P. jullieni the $5 \mathrm{~S}$ rDNA genes are located on three chromosomal pairs (\#23, \#24, $\# 25$ ), while the $18 \mathrm{~S}$ rDNA are in another three ones (\#19, \#35, \#36). Consequently, no co-localization of rDNA classes in the genome of either species was detected (Fig. 1).

\section{Chromosomal mapping of microsatellite sequences}

The mapping of the three short repetitive sequences, $(\mathrm{A})_{30},(\mathrm{CA})_{15}$ and $(\mathrm{GA})_{15}$, showed the same hybridization patterns in both species. While $(\mathrm{A})_{30}$ presented a scattered distribution among all chromosomes, the other two motifs $(\mathrm{CA})_{15}$ and $(\mathrm{GA})_{15}$ are both accumulated in the telomeric regions of several chromosome pairs (Fig. 2).

\section{Discussion}

Despite the sporadic occurrence in higher vertebrates, polyploidy was repeatedly documented across several fish lineages and at different taxonomic levels, implying its independent and recurrent origin [24-27]. Out of the four species placed in the tribe Probarbini, just two $-P$. jullieni and C. siamensis - have previously been cytogenetically analyzed. Suzuki and Taki [22] reported for the former species $2 \mathrm{n}=98(18 \mathrm{~m}+54 \mathrm{sm} / \mathrm{st}+26 \mathrm{a})$ and the follow-up study from the same authors [23] showed $2 n=98(18 m+28 \mathrm{sm} / \mathrm{st}+52 \mathrm{a})$ for the latter species. Our results confirmed $2 \mathrm{n}$ for both species but with small differences in the karyotype composition. This incongruence reflects probably the small size of the cyprinid chromosomes, especially those of polyploids.
Furthermore, cyprinid chromosomes also exhibit a gradual decrease in size, with the centromere positions ranging step-wisely from median to nearly terminal. Indeed, these features make it difficult to assess the chromosomal categories with accuracy [28-30].

Another important aspect of the comparative cytotaxonomy associated with Probarbini species analyzed herein is their slightly reduced $2 n=98$ from the usual $2 n=100$ that occurs in the overwhelming majority of the polyploid cyprinids [19]. Representatives of the Schizothoracini and Schizopygopsini tribes, the most ones phylogenetically distant from the Probarbini [9], also display a reduced chromosome number ranging from 90 to 98 [31-38]. In this sense, such 2 n reductions seem to be a result of independent evolutionary events. As most of other paleotetraploid cyprinine taxa have $2 \mathrm{n}=100$, 98 chromosomes found in both species examined here likely represent a derived feature. We suppose that the reduced $2 n=98$ might be a shared derived character for species of the whole Probarbini clade. Yet, 2n counts for the two remaining members of this group, i.e. P. labeamajor and $P$. labeaminor, remain yet to be determined. An obvious but still unclear question is what evolutionary background stands beyond this 2 n reduction? Probarbini are highly potamodromous fishes, while the representatives of the other two lineages are confined to high altitudes in Qinghai-Tibetan plateau, forming small, highly fragmented populations [39]. These lineages also contain hexaploid forms [33] or even triploid derivative of this hexaploid level [40] suggesting complex evolutionary processes.

Rapid changes for content in polyploid genomes represent an integral part of very complex processes leading to both immediate and long-term post-polyploidization

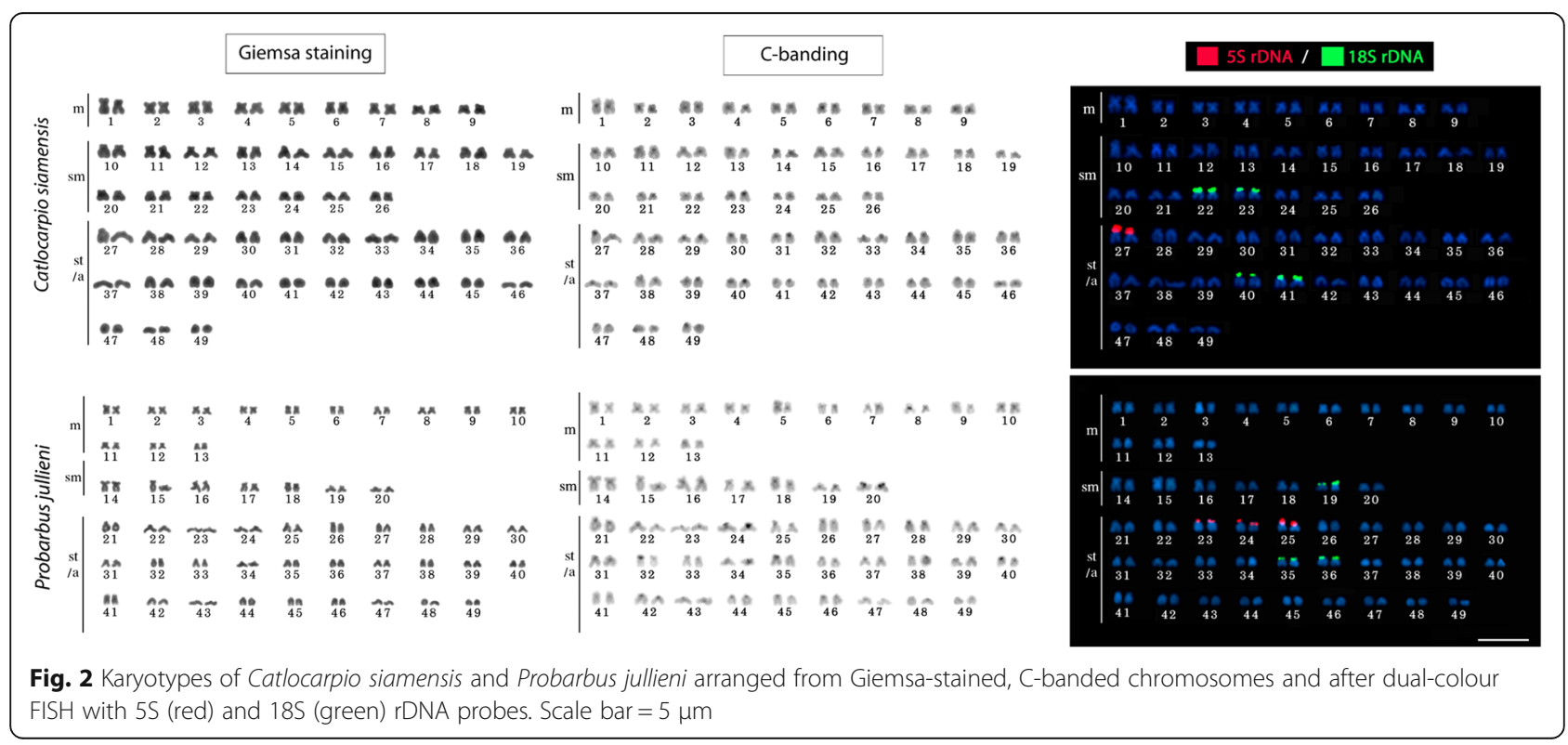


alterations, involving restructuring of genome architecture, epigenetic landscape and gene expression patterns. These processes lead to gradual re-diploidization, i.e. re-establishment of genome balance and diploid-like inheritance [41-49]. Repetitive DNA sequences may be either lost during the process of the so-called genome downsizing, or they can be amplified and/or accumulated in gene-poor regions. Such changes may be driven by illegitimate (non-homologous) recombination and deregulated control of (retro) transposition activity [43, 44, 47, 50-52].

Therefore, the mapping of repetitive DNA classes might provide a useful tool for elucidating the dynamics of (especially young) post-polyploid genomes. Alike the comprehensive cytogenetic maps produced for plant neopolyploids e.g. [53-55], similar research in fishes is mainly restricted to mapping of tandemly-repeated clusters of major (nucleolus-forming, 45S) and minor (5S) rDNA classes as they are the most utilized markers in fish cytotaxonomy in general [28, 56-59]. However, studies performing cytogenetic mapping of e.g. several markers such as Hox genes or satellite DNAs, in conjunction with recent advances in genome sequencing and bioinformatics, are also starting to be implemented typically in non-teleost acipenserids [60, 61]. Regarding rDNA profiles, they proved useful especially in deciphering the origin of rather recent homoploid or polyploid hybrids, because the intermediate pattern might help to identify the parental species [62-66]. Moreover, if the numbers of rDNA sites remain additive in polyploids of uncertain origin, the mechanism of either auto- or allopolyploidy might be inferred [67-69]. However, both rDNA classes are subjected to dynamic and complementary evolutionary forces leading either to intragenomic sequence homogenization (concerted evolution), or to the emergence of new repeat variants (birth-and-death evolution) [70-76]. In polyploids, these processes are further modified by the nature of polyploidy, with nucleolar dominance $[71,77,78]$ and chimeric sequence variants (described also in cyprinids [72-75]) being a typical example found in allopolyploids. Finally, deregulated control of (retro) transposition activity, especially in hybrid genomes, may further greatly contribute to rDNA site number instability/ hypervariability [76], as both rDNA classes are known to be frequent targets for insertion of various mobile elements [79-83]. All these processes are adding complexity to rDNA dynamics and may disable smooth usage of these markers for examination of karyotype differentiation processes. To name a few examples, high polymorphism and/or rapid amplification of rDNA sites were found in homoploid or polyploid cyprinid fishes [29, 62, 84-86] as well as in other paleo- or neopolyploid fish taxa across the teleost phylogeny [58, 87]. However, also some diploid cyprinids might pose a challenge in terms of rDNA site number analysis due to varied degree of intra- or interindividual polymorphism $[88,89]$ and interspecific variability $[90,91]$.

In this study, the number and distribution of ribosomal genes were not conserved among both analyzed species. Thus, whereas two and eight $5 \mathrm{~S}$ and $18 \mathrm{~S}$ rDNA signals, respectively, were mapped on the chromosomes of $C$. siamensis, a total of six signals for both rDNA classes was observed in the P. jullieni karyotype (Fig. 1). Considering only the strictly polyploid taxa, the distribution patterns of the rDNA sites among the cyprinid lineages remain poorly covered $[29,30]$, except for some representatives of the Torini and Cyprinini tribes. The available data for five Indian species of the genus Tor (Torini) $[21,84,85]$ demonstrate very similar pattern as found in our present study, i.e., either single or multiple chromosome pairs carrying both ribosomal clusters. However, the genomes of several members of the clade Cyprinini were examined more thoroughly for these markers [19]; also they exhibit variable site numbers for both rDNA classes. As an example, the common carp Cyprinus carpio, with a (paleo) tetraploid karyotype $2 n=100$, exhibits a re-diploidized pattern for $45 \mathrm{~S}$ rDNA, with only a single chromosome pair carrying such sites [92, 93]. Also four to eight 5S rDNA loci [94] can be observed there, while in the (paleo-) tetraploid crucian carp Carassius carassius the major rDNA sites occupy two different chromosomal pairs, and the minor rDNA encompasses a variable number of 8-18 loci $[29,30]$. Besides, a comparable variability of rDNA distribution was also present in several polyploid forms of $C$. auratus complex [63, 67, 95]. While some reports have evidenced co-localized sites of $5 \mathrm{~S}$ and $45 \mathrm{~S}$ rDNA clusters in several either diploid or polyploid cyprinids [62, 86, 94, 96], this is not the case for the species studied herein. Finally, the multiple $45 \mathrm{~S}$ rDNA sites in both Probarbini species display only slight site-number changes, while $5 \mathrm{~S}$ rDNA shows a re-diploidized condition in C. siamensis - accompanied, however, by apparently larger sizes of both homologous loci. Complementary analyses in the remaining Probarbini species, $P$. labeamajor and $P$. labeaminor, will complete the picture of the post-polyploid rDNA dynamics in this clade. However, from the current data, probable mechanisms such as unequal crossing overs, illegitimate recombination and also transpositions might account for the observed patterns, possibly facilitated by the allopolyploid/hybrid origin of the species.

Microsatellites or simple sequence repeats (SSRs) are oligonucleotides of 1-6 base pairs in length, forming excessive tandem repeats of usually four-to-40 units [97-99]. They show abundant distribution throughout eukaryotic genomes, being dispersed or clustered both in euchromatin or heterochromatin. They are highly polymorphic regarding copy number variations [98]. In the fish genomes, microsatellites are usually abundant in the centromeric 
and telomeric regions, and they can also localize preferentially to sex chromosomes [56, 100, 101]. In our study, both species exhibited the same general hybridization pattern for all applied probes, with the motif $(\mathrm{A})_{30}$ showing moderate abundance and dispersed hybridization pattern throughout the genomes. Otherwise, the dinucleotides $(\mathrm{CA})_{15}$ and (GA) 15 accumulated exclusively in telomeric and subtelomeric chromosomal regions, corroborating findings from other fish groups studied to date [101-107]. While the bearing of the observed patterns to the dynamics of polyploidy remains unclear, some authors $[104,107]$ suggested that the preferential targeting of $(\mathrm{CA})_{15}$ and $(\mathrm{GA})_{15}$ and other microsatellite motifs to telomeric and subtelomeric regions might be functionally linked with the structural formation of telomeres. As microsatellites can be found to be embedded within rDNA clusters [108] and all rDNA sites turned out to be terminal in both species under study, we suppose that $(\mathrm{CA})_{15}$ and $(\mathrm{GA})_{15}$ dinucleotides might have contributed to the dynamic behavior of rDNA sites in these Probarbini representatives.

\section{Methods}

\section{Animals}

Individuals of Catlocarpio siamensis (12 $\hat{\sigma}$ and $6 \circ$ ) and Probarbus jullieni ( $8 \widehat{\gamma}$ and $8 \odot$ ) from different tributaries of the Mekong River basin (Thailand) were analyzed (Fig. 3). The specimens were caught using a hand-net, placed in sealed plastic bags containing oxygen and clean water, and transported to the laboratory. Experiments were performed in accordance with ethical protocols, and anesthesia-using clove oil was administered prior to sacrificing the animals, as approved by the Ethics Committee of Khon Kaen University and by the RGJ committee under no. PHD/K0081/2556 (Thailand).
The specimens were deposited in the fish collection of the Cytogenetic Laboratory, Department of Biology Faculty of Science, Khon Kaen University (Thailand).

\section{Chromosome preparation and C-banding}

Mitotic chromosomes were obtained from the anterior kidney, cell suspensions dropped onto microscopic slides and air-dried [109]. Conventional staining was done by $5 \%$ Giemsa solution in phosphate buffer $(\mathrm{pH} 6.8)$ for $10 \mathrm{~min}$. The distribution of constitutive heterochromatin on chromosomes was demonstrated by C-banding method [110].

\section{The probe preparation and FISH experiments}

Two tandemly arrayed rDNA sequences, namely $5 \mathrm{~S}$ and 18 , were obtained via PCR from the nuclear DNA of $C$. siamensis. The $5 \mathrm{~S}$ repeat copy encompassing 120 base pairs (bp) of the 5S rRNA coding region and $200 \mathrm{bp}$ of the non-transcribed spacer (NTS) was produced according to Pendas et al. [111]. The 18S rDNA fragment, with 1,400-bp in length including the $18 \mathrm{~S}$ rRNA gene coding sequence, was prepared according to Cioffi et al. [112]. Both rDNA fragments were cloned into plasmid vectors and propagated in DH5 $\alpha$ Escherichia coli competent cells (Invitrogen, San Diego, CA, USA). The final 5S and 18S rDNA probes were directly labeled with SpectrumOrange-dUTP and SpectrumGreen-dUTP, respectively, by Nick translation kit (Roche, Mannheim, Germany) according to the manufacturer's recommendations. FISH was performed under high stringency conditions following the protocol of Yano et al. [113].

FISH with the set of probes corresponding to three microsatellite motifs $(\mathrm{A})_{30},(\mathrm{CA})_{15}$ and $(\mathrm{GA})_{15}$ was performed as described in [114], with slight modifications.

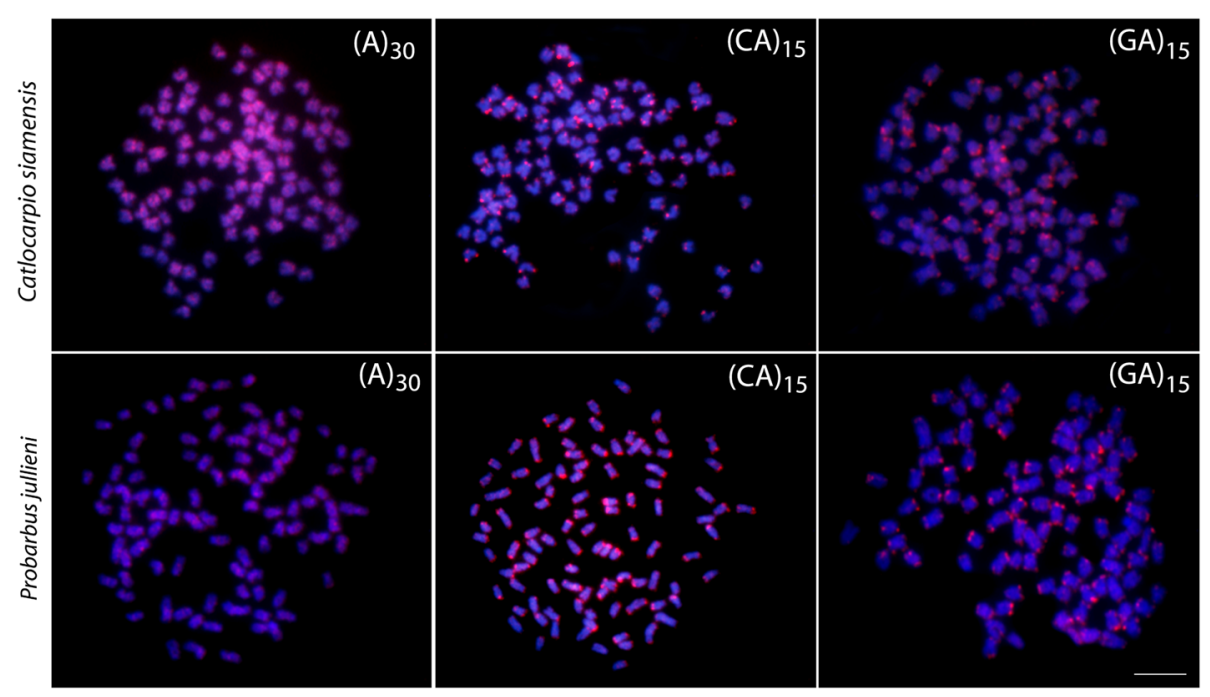

Fig. 3 Metaphase plates of Catlocarpio siamensis and Probarbus jullieni after FISH with different microsatellite motifs. Scale bar $=5 \mu m$ 
These sequences were directly labeled by Cy3 at the 5' terminus during synthesis (Sigma, St. Louis, MO, USA).

Chromosomes were counterstained with DAPI $(1.2 \mu \mathrm{g} / \mathrm{ml})$ and mounted in antifading solution (Vector, Burlingame, CA, USA,) in both experiments.

\section{Image processing}

At least 30 metaphase spreads per individual were analyzed to confirm the diploid number, karyotype structure and FISH data. Images were captured using an Olympus BX50 microscope (Olympus Corporation, Ishikawa, Japan) with CoolSNAP and processed using Image Pro Plus 4.1 software (Media Cybernetics, Silver Spring, MD, USA). Chromosomes were classified according to centromere position as metacentric (m), submetacentric ( $\mathrm{sm}$ ) and subtelocentric (st)/acrocentric (a) ones [115], with the st and a chromosome pairs being scored together in one st-a category. For the chromosomal arm number (NF; Nombre Fondamental) to be calculated, $\mathrm{m}+\mathrm{sm}$ were scored as bi-armed while st + as mono-armed.

\section{Conclusions}

Here we hypothesized that the karyotype characterized by $2 n=98$ in both analyzed species might represent a derived character, probably also shared by all members of the Probarbini clade. Besides, we also witnessed considerable changes in the amount and distribution of certain repetitive DNA classes, hence suggesting complex post-polyploidization processes in this small paleotetraploid tribe.

\section{Abbreviations \\ 2n: Diploid number; a: acrocentric chromosome; DAPI: 4',6-diamidino-2- phenylindole; dUTP: 2'-Deoxyuridine-5'-Triphosphate; FISH: Fluorescence in situ hybridization; m: metacentric chromosome; NF: Nombre Fondamental; NTS: Non-transcribed spacer; PCR: Polymerase chain reaction; rDNA: ribosomal DNA; rRNA: ribosomal RNA; sm: submetacentric chromosome; st: subtelocentric chromosome}

\section{Funding}

This work was financially supported by: The Thailand Research Fund (TRF) through the Royal Golden Jubilee Ph.D. Program Grant No. PHD/0140/2557 and Toxic Substances in Livestock and Aquatic Animals Research Group, Khon Kaen University; scholarship under the Post-Doctoral Trainning Program from Research Affairs and Graduate School (Grant No. 59255). The funders had no role in study design, data collection; Project EXCELLENCE CZ.02.1.01/ 0.0/0.0/15 003/0000460 OP RDE (PR) and with the institutional support RVO: 67985904 (PR, AS) by the Czech Academy of Sciences; Conselho Nacional de Desenvolvimento Científico e Tecnológico - CNPq (Proc. nos 401962/2016-4 and 304992/2015-1), Fundação de Amparo à Pesquisa do Estado de São PauloFAPESP (Proc. No 2016/22196-2) and CAPES/Alexander von Humboldt (Proc. No. 88881.136128/2017-01).

\section{Availability of data and materials}

Data sharing is not applicable to this article as no datasets were generated or analysed during the current study.

\section{Authors' contributions}

PS, EAO, CFY and TH carried out the cytogenetic analysis and drafted the manuscript, MBC, AT, WS and SP helped in the cytogenetic analysis, drafted and revised the manuscript. MJCP, AS, LACB, TL and PR drafted and revised the manuscript. MBC, AT and PR coordinated the study, drafted and revised the manuscript. All authors read and approved the final version of the manuscript.

\section{Ethics approval and consent to participate}

Experiments were performed in accordance with ethical protocols, and anesthesia using clove oil was administered prior to sacrificing the animals, as approved by the Ethics Committee of Khon Kaen University and by the RGJ committee under no. PHD/K0081/2556.

\section{Consent for publication}

Not applicable

\section{Competing interests}

The authors declare that they have no competing interests.

\section{Publisher's Note}

Springer Nature remains neutral with regard to jurisdictional claims in published maps and institutional affiliations.

\section{Author details}

${ }^{1}$ Toxic Substances in Livestock and Aquatic Animals Research Group, Department of Biology, Faculty of Science, Khon Kaen University, Muang District, Khon Kaen, Thailand. 'Departamento de Genética e Evolução, Universidade Federal de São Carlos, São Carlos, SP, Brazil. ${ }^{3}$ Secretaria de Estado de Educação de Mato Grosso - SEDUC-MT, Cuiabá, MT, Brazil. ${ }^{4}$ Faculty of Applied Science and Engineering, Khon Kaen University, Nong Kai Campus, Muang, Nong Kai, Thailand. ${ }^{5}$ Faculdade de Ciencias, Centre for Ecology, Evolution and Environmental Changes, Universidade de Lisboa, Campo Grande, PT-1749-016 Lisbon, Portugal. '́Laboratory of Fish Genetics, Institute of Animal Physiology and Genetics, Czech Academy of Sciences, Rumburská 89, 27721 Liběchov, Czech Republic. 'Institute of Human Genetics, Jena University Hospital, Am Klinikum 1, D-07747 Jena, Germany.

Received: 16 July 2018 Accepted: 23 August 2018

Published online: 04 September 2018

\section{References}

1. Hurley IA, Mueller RL, Dunn KA, Schmidt EJ, Friedman M, Ho RK, et al. A new time-scale for ray-finned fish evolution. Proc R Soc London B Biol Sci. 2007;274:489-98.

2. Braasch I, Postlethwait JH. Polyploidy in fish and the teleost genome duplication. In: Soltis PS, Soltis DE, editors. Polyploidy and genome evolution. Berlin: Springer; 2012. p. 341-83.

3. Sallan LC. Major issues in the origins of ray-finned fish (Actinopterygii) biodiversity. Biol Rev. 2014;89:950-71.

4. Uyeno T, Smith GR. Tetraploid origin of the karyotype of catostomid fishes. Science. 1972;175:644-6.

5. Saitoh K, Chen W-J, Mayden RL. Extensive hybridization and tetrapolyploidy in spined loach fish. Mol Phylogenet Evol. 2010;56:1001-10.

6. Alexandrou MA, Oliveira C, Maillard M, McGill RAR, Newton J, Creer S, et al. Competition and phylogeny determine community structure in Müllerian co-mimics. Nature. 2011;469:84.

7. Marburger S, Alexandrou MA, Taggart JB, Creer S, Carvalho G, Oliveira C, et al. Whole genome duplication and transposable element proliferation drive genome expansion in Corydoradinae catfishes. Proc R Soc B. 2018;285: 20172732.

8. Macqueen DJ, Johnston IA. A well-constrained estimate for the timing of the salmonid whole genome duplication reveals major decoupling from species diversification. Proc R Soc B Biol Sci. 2014;281:20132881.

9. Yang L, Sado T, Vincent Hirt M, Pasco-Viel E, Arunachalam M, Li J, et al. Phylogeny and polyploidy: resolving the classification of cyprinine fishes (Teleostei: Cypriniformes). Mol Phylogenet Evol. 2015;85:97-116.

10. Schmidt RC, Bart HL Jr. Nomenclatural changes should not be based on equivocally supported phylogenies: reply to Yang et al. 2015. Mol Phylogenet Evol. 2015;90:193-4.

11. Wang X, Gan X, Li J, Chen Y, He S. Cyprininae phylogeny revealed independent origins of the Tibetan plateau endemic polyploid cyprinids and their diversifications related to the Neogene uplift of the plateau. Sci China Life Sci. 2016;59:1149-65.

12. Smith HM. The freshwater fishes of Siam, or Thailand. Bull - United States Natl Museum. 1945;188:1-633. 
13. Rainboth WJ. Fishes of the cambodian mekong. Rome: Food \& Agriculture Org.; 1996.

14. Robert TR. Revision of the southeast Asian cyprinid fish genus Probarbus, with two new species threatened by proposed construction of dams on the Mekong River. Ichthyol Explor Freshwaters. 1992;3:37-48.

15. Hogan Z, Baird I. Probarbus jullieni. The IUCN Red List of Threatened Species. 2011. https://doi.org/10.2305/IUCN.UK.2011-1.RLTS.T18182A7742599.en. Accessed 6 Sep 2017.

16. Baird I. Probarbus labeamajor. The IUCN Red List of Threatened Species. 2011. https://doi.org/10.2305/IUCN.UK.2011-1.RLTS.T18183A7744836.en. Accessed 6 Sep 2017

17. Baird I. Probarbus labeaminor. The IUCN Red List of Threatened Species 2012 https://doi.org/10.2305/IUCN.UK.2012-1.RLTS.T18184A1728617.en. Accessed 6 Sep 2017

18. Hogan Z. Catlocarpio siamensis. The IUCN Red List of Threatened Species. 2011. https://doi.org/10.2305/IUCN.UK.2011-1.RLTS.T180662A7649359.en. Accessed 6 Sep 2017.

19. Arai R. Fish karyotypes: a check list. Tokio: Springer Science \& Business Media; 2011.

20. Singh M, Kumar R, Nagpure NS, Kushwaha B, Gond I, Lakra WS. Chromosomal localization of $18 \mathrm{~s}$ and $5 \mathrm{~s}$ rDNA using FISH in the genus Tor (Pisces, Cyprinidae). Genetica. 2009;137:245-52.

21. Mani I, Kumar R, Singh M, Nagpure NS, Kushwaha B, Srivastava PK, et al. Nucleotide variation and physical mapping of ribosomal genes using FISH in genus Tor (Pisces, Cyprinidae). Mol Biol Rep. 2011;38:2637-47.

22. Suzuki A, Taki Y. Chromosomes and DNA values of two cyprinid fishes of the subfamily Barbinae. Japanese J Ichthyol. 1986;32:459-62.

23. Suzuki A, Taki Y. Karyotype and DNA content in the cyprinid Catlocarpio siamensis. Japanese J Ichthyol. 1988;35:389-91.

24. Otto SP, Whitton J. Polyploid incidence and evolution. Annu Rev Genet. 2000;34:401-37

25. Le Comber SC, Smith C. Polyploidy in fishes: patterns and processes. Biol J Linn Soc. 2004:82:431-42.

26. Mable BK, Alexandrou MA, Taylor MI. Genome duplication in amphibians and fish: an extended synthesis. J Zool. 2011;284:151-82.

27. Glasauer SMK, Neuhauss SCF. Whole-genome duplication in teleost fishes and its evolutionary consequences. Mol Gen Genomics. 2014;289:1045-60.

28. Ráb P, Collares-Pereira MJ. Chromosomes of European cyprinid fishes (Cyprinidae, Cypriniformes). A review. Folia Zool. 1995;44:193-214.

29. Spoz A, Boron A, Porycka K, Karolewska M, Ito D, Abe S, et al. Molecular cytogenetic analysis of the crucian carp, Carassius carassius (Linnaeus, 1758)(Teleostei, Cyprinidae), using chromosome staining and fluorescence in situ hybridisation with rDNA probes. Comp Cytogenet. 2014;8:233-48.

30. Knytl M, Kalous L, Rylková K, Choleva L, Merilä J, Ráb P. Morphologically indistinguishable hybrid Carassius female with 156 chromosomes: a threat for the threatened crucian carp, C. carassius, L. PLoS One. 2018;13:e0190924.

31. Rishi KK, Singh J, Kaul MM. Chromosome analysis of Schizothoracichthys progastus (McCll) (Cypriniformes). Chromosom Inform Serv. 1983;34:12-3.

32. Rishi KK, Rishi S. Karyotype study on six Indian hill-stream fishes. Chromosom Sci. 1998;2:9-13.

33. Zan RG, Liu WG, Song Z. Tetraploid-hexaploid relationship in Schizothoracinae. Acta Genet Sin. 1985;12:137-42.

34. Mazik EJ, Toktosunovic A, Ráb P. Karyotype study of four species of the genus Diptychus (Pisces, Cyprinidae), with remarks on polyploidy of schizothoracine fishes. Folia Zool. 1989;38:325-32.

35. Ahmad F, Yousuf AR, Tripathi NK, Zargar UR. On the chromosomes of two cyprinid fishes of the subfamily Schizothoracinae from Kashmir. Nat Sci. 2011;9:53-61.

36. Yu X, Zhou T, Li K, Li Y, Zhou M. On the karyosystematics of cyprinid fishes and a summary of fish chromosome studies in China. Genetica. 1987;72:225-35

37. Yu XJ, Zhou T, Li YC, Li K, Zhou M. Chromosomes of Chinese freshwater fishes. Beijing: Science Press; 1989.

38. Yu XY, Li YC, Zhou T. Karyotype studies of cyprinid fishes in Chinacomparative study of the karyotypes of 8 species of schizothoracine fishes. Wuhan Univ J Nat Sci. 1990:2:97-104.

39. He D, Chen Y, Chen Y, Chen Z. Molecular phylogeny of the specialized schizothoracine fishes (Teleostei: Cyprinidae), with their implications for the uplift of the Qinghai-Tibetan Plateau. Chin Sci Bull. 2004;49:39-48.

40. Yu XY, Yu XJ. A schizothoracine fish species, Diptychus dipogon, with a very high number of chromosomes. Chromosom Inf Serv. 1990;48:17-8.
41. Wolfe KH. Yesterday's polyploids and the mystery of diploidization. Nat Rev Genet. 2001;2:333-41.

42. Comai L. The advantages and disadvantages of being polyploid. Nat Rev Genet. 2005;6:836-46. https://doi.org/10.1038/nrg1711.

43. Ma X-F, Gustafson JP. Genome evolution of allopolyploids: a process of cytological and genetic diploidization. Cytogenet Genome Res. 2005; 109:236-49.

44. Leitch IJ, Hanson L, Lim KY, Kovarik A, Chase MW, Clarkson JJ, et al. The ups and downs of genome size evolution in polyploid species of Nicotiana (Solanaceae). Ann Bot. 2008;101:805-14.

45. Parisod C, Holderegger R, Brochmann C. Evolutionary consequences of autopolyploidy. New Phytol. 2010;186:5-17.

46. Madlung A. Polyploidy and its effect on evolutionary success: old questions revisited with new tools. Heredity. 2013;110:99-104.

47. Tayalé A, Parisod C. Natural pathways to polyploidy in plants and consequences for genome reorganization. Cytogenet Genome Res. 2013;140:79-96.

48. Wertheim B, Beukeboom LW, Van de Zande L. Polyploidy in animals: effects of gene expression on sex determination, evolution and ecology. Cytogenet Genome Res. 2013;140:256-69.

49. Soltis DE, Visger CJ, Marchant DB, Soltis PS. Polyploidy: pitfalls and paths to a paradigm. Am J Bot. 2016;103:1146-66.

50. Schwarzacher T, Leitch AR, Bennett MD, Heslop-Harrison JS. In situ localization of parental genomes in a wide hybrid. Ann Bot. 1989;64:315-24.

51. Leitch IJ, Bennett MD. Genome downsizing in polyploid plants. Biol J Linn Soc. 2004:82:651-63.

52. Parisod C, Alix K, Just J, Petit M, Sarilar V, Mhiri C, et al. Impact of transposable elements on the organization and function of allopolyploid genomes. New Phytol. 2010;186:37-45.

53. Chester M, Leitch AR, Soltis PS, Soltis DE. Review of the application of modern cytogenetic methods (FISH/GISH) to the study of reticulation (polyploidy/hybridisation). Genes (Basel). 2010;1:166-92.

54. Xiong Z, Pires JC. Karyotype and identification of all homoeologous chromosomes of allopolyploid Brassica napus and its diploid progenitors. Genetics. 2011:187:37-49.

55. Cuadrado Á, de Bustos A, Jouve N. On the allopolyploid origin and genome structure of the closely related species Hordeum secalinum and Hordeum capense inferred by molecular karyotyping. Ann Bot. 2017;120:245-55.

56. Cioffi MB, Bertollo LAC. Chromosomal distribution and evolution of repetitive DNAs in fish. In: Garrido-Ramos MA, editor. Genome dynamics. Basel: Karger; 2012. p. 197-221.

57. Gornung E. Twenty years of physical mapping of major ribosomal RNA genes across the teleosts: a review of research. Cytogenet Genome Res. 2013;141:90-102.

58. Maneechot N, Yano CF, Bertollo LAC, Getlekha N, Molina WF, Ditcharoen $\mathrm{S}$, et al. Genomic organization of repetitive DNAs highlights chromosomal evolution in the genus Clarias (Clariidae, Siluriformes). Mo Cytogenet. 2016;9:4

59. Sochorová J, Garcia S, Gálvez F, Symonová R, Kovařík A. Evolutionary trends in animal ribosomal DNA loci: introduction to a new online database. Chromosoma. 2018;127:141-50.

60. Biltueva LS, Prokopov DY, Makunin Al, Komissarov AS, Kudryavtseva AV, Lemskaya NA, et al. Genomic organization and physical mapping of tandemly arranged repetitive DNAs in sterlet (Acipenser ruthenus). Cytogenet Genome Res. 2017;152:148-57.

61. Symonová $R$, Havelka $M$, Amemiya $C T$, Howell WM, Kořínková $T$, Flajšhans $M$, et al. Molecular cytogenetic differentiation of paralogs of Hox paralogs in duplicated and re-diploidized genome of the north American paddlefish (Polyodon spathula). BMC Genet. 2017;18:19.

62. Gromicho M, Coutanceau J-P, Ozouf-Costaz C, Collares-Pereira MJ. Contrast between extensive variation of 28S rDNA and stability of 5S rDNA and telomeric repeats in the diploid-polyploid Squalius alburnoides complex and in its maternal ancestor Squalius pyrenaicus (Teleostei, Cyprinidae). Chromosom Res. 2006;14:297-306.

63. Zhu H-P, Gui J-F. Identification of genome organization in the unusual allotetraploid form of Carassius auratus gibelio. Aquaculture. 2007;265:109-17.

64. Da Silva M, Matoso DA, Ludwig LAM, Gomes E, Almeida MC, Vicari MR, et al. Natural triploidy in Rhamdia quelen identified by cytogenetic monitoring in Iguaçu basin, southern Brazil. Environ Biol Fish. 2011;91:361-6.

65. Zhang C, Ye L, Chen Y, Xiao J, Wu Y, Tao M, et al. The chromosomal constitution of fish hybrid lineage revealed by $5 S$ rDNA FISH. BMC Genet. 2015;16:140. 
66. Ribeiro LB, Moraes Neto A, Artoni RF, Matoso DA, Feldberg E. Chromosomal mapping of repetitive sequences (Rex3, Rex6, and rDNA Genes) in hybrids between Colossoma macropomum (Cuvier, 1818) and Piaractus mesopotamicus (Holmberg, 1887). Zebrafish. 2017;14:155-60.

67. Zhu HP, Ma DM, Gui JF. Triploid origin of the gibel carp as revealed by 55 rDNA localization and chromosome painting. Chromosom Res. 2006;14:767-76.

68. Li Y-J, Tian Y, Zhang M-Z, Tian P-P, Yu Z, Abe S, et al. Chromosome banding and FISH with rDNA probe in the diploid and tetraploid loach Misgurnus anguillicaudatus. Ichthyol Res. 2010;57:358-66.

69. Qin Q, Wang J, Hu M, Huang S, Liu S. Autotriploid origin of Carassius auratus as revealed by chromosomal locus analysis. Sci China Life Sci. 2016;59:622-6.

70. Eickbush TH, Eickbush DG. Finely orchestrated movements: evolution of the ribosomal RNA genes. Genetics. 2007;175:477-85.

71. Feliner GN, Rosselló JA. Concerted evolution of multigene families and homoeologous recombination. In: Wendel JF, editor. Plant genome diversity volume 1. Vienna: Springer-Verlag; 2012. p. 171-93.

72. Qin Q, He W, Liu S, Wang J, Xiao J, Liu Y. Analysis of 5 S rDNA organization and variation in polyploid hybrids from crosses of different fish subfamilies. J Exp Zool Part B Mol Dev Evol. 2010;314:403-11.

73. He W, Qin Q, Liu S, Li T, Wang J, Xiao J, et al. Organization and variation analysis of $5 \mathrm{~S}$ rDNA in different ploidy-level hybrids of red crucian carp $\times$ topmouth culter. PLoS One. 2012;7:e38976.

74. Huang $P$, Xiao A, Tong X, Lin S, Zhang B. Targeted mutagenesis in zebrafish by TALENs. In: Clifton NJ, editor. Methods in molecular biology. New Jersey: Human Press; 2016. p. 191-206.

75. Ye L, Zhang C, Tang X, Chen Y, Liu S. Variations in 5 S rDNAs in diploid and tetraploid offspring of red crucian carp × common carp. BMC Genet. 2017;18:75.

76. Fontdevila A. Hybrid genome evolution by transposition. Cytogenet Genome Res. 2005;110:49-55.

77. Volkov RA, Komarova NY, Hemleben V. Ribosomal DNA in plant hybrids: inheritance, rearrangement, expression. Syst Biodivers. 2007;5:261-76.

78. Kovarik A, Dadejova M, Lim YK, Chase MW, Clarkson JJ, Knapp S, et al. Evolution of rDNA in Nicotiana allopolyploids: a potential link between rDNA homogenization and epigenetics. Ann Bot. 2008;101:815-23.

79. Rebordinos L, Cross I, Merlo A. High evolutionary dynamism in 5S rDNA of fish: state of the art. Cytogenet Genome Res. 2013;141:103-13.

80. Zhang $X$, Eickbush MT, Eickbush TH. Role of recombination in the longterm retention of transposable elements in rRNA gene loci. Genetics. 2008;180:1617-26.

81. Cioffi MB, Martins C, Bertollo LAC. Chromosome spreading of associated transposable elements and ribossomal DNA in the fish Erythrinus erythrinus. Implications for genome change and karyoevolution in fish. BMC Evol Biol. 2010;10:271

82. Symonová R, Majtánová Z, Sember A, Staaks GBO, Bohlen J, Freyhof J. Genome differentiation in a species pair of coregonine fishes: an extremely rapid speciation driven by stress - activated retrotransposons mediating extensive ribosomal DNA multiplications. BMC Evol Biol. 2013;13:42.

83. Sember A, Bohlen J, Šlechtová V, Altmanová M, Symonová R, Ráb P. Karyotype differentiation in 19 species of river loach fishes (Nemacheilidae, Teleostei): extensive variability associated with rDNA and heterochromatin distribution and its phylogenetic and ecological interpretation. BMC Evol Biol. 2015;15:251.

84. Singh M, Kumar R, Nagpure NS, Kushwaha B, Mani I, Chauhan UK, et al. Population distribution of $45 \mathrm{~S}$ and $5 \mathrm{~S}$ rDNA in golden mahseer, Tor putitora: population-specific FISH marker. J Genet. 2009;88:315-20.

85. Singh M, Kumar R, Nagpure NS, Kushwaha B, Mani I, Lakra WS. Extensive NOR site polymorphism in geographically isolated populations of golden mahseer, Tor putitora. Genome. 2009;52:783-9.

86. Pereira CSA, Aboim MA, Ráb P, Collares-Pereira MJ. Introgressive hybridization as a promoter of genome reshuffling in natural homoploid fish hybrids (Cyprinidae, Leuciscinae). Heredity. 2014;112:343-50.

87. Śliwińska-Jewsiewicka A, Kuciński M, Kirtiklis L, Dobosz S, Ocalewicz K, Jankun M. Chromosomal characteristics and distribution of rDNA sequences in the brook trout Salvelinus fontinalis (Mitchill, 1814). Genetica. 2015;143:425-32.

88. Collares-Pereira MJ, Ráb P. NOR polymorphism in the Iberian species Chondrostoma lusitanicum (Pisces: Cyprinidae)-re-examination by FISH. Genetica. 1999;105:301-3.

89. Libertini A, Sola L, Rampin M, Rossi AR, lijima K, Ueda T. Classical and molecular cytogenetic characterization of allochthonous European bitterling Rhodeus amarus (Cyprinidae, Acheilognathinae) from northern Italy. Genes Genet Syst. 2008:83:417-22.
90. Pereira CSA, Ráb P, Collares-Pereira MJ. Chromosomes of European cyprinid fishes: comparative cytogenetics and chromosomal characteristics of ribosomal DNAs in nine Iberian chondrostomine species (Leuciscinae). Genetica. 2012;140:485-95.

91. Rossi AR, Milana V, Hett AK, Tancioni L. Molecular cytogenetic analysis of the Appenine endemic cyprinid fish Squalius lucumonis and three other Italian leuciscines using chromosome banding and FISH with rDNA probes. Genetica. 2012;140:469-76.

92. Li Y-J, Gao Y-C, Zhou H, Liu B, Gao M, Wang Y-S, et al. Molecular cytogenetic study of genome ploidy in the German mirror carp Cyprinus carpio. Fish Sci. 2014;80:963-8.

93. Kumar R, Baisvar VS, Kushwaha B, Waikhom G, Nagpure NS. Cytogenetic investigation of Cyprinus carpio (Linnaeus, 1758) using giemsa, silver nitrate, CMA 3 staining and fluorescence in situ hybridization. Nucl. 2017;60:1-8.

94. Inafuku J, Nabeyama M, Kikuma Y, Saitoh J, Kubota S, Kohno S. Chromosomal location and nucleotide sequences of $5 S$ ribosomal DNA of two cyprinid species (Osteichthyes, Pisces). Chromosom Res. 2000;8:193-9.

95. Murakami M, Fujitani $\mathrm{H}$. Characterization of repetitive DNA sequences carrying $5 \mathrm{~S}$ rDNA of the triploid ginbuna (Japanese silver crucian carp, Carassius auratus langsdorfi). Genes Genet Syst. 1998;73:9-20.

96. Phillips RB, Reed KM. Localization of repetitive DNAs to zebrafish (Danio rerio) chromosomes by fluorescence in situ hybridization (FISH). Chromosom Res. 2000;8:27-35.

97. Tautz D, Renz M. Simple sequences are ubiquitous repetitive components of eukaryotic genomes. Nucleic acids Res Acids Res. 1984;12:4127-38.

98. Ellegren H. Microsatellites: simple sequences with complex evolution. Nat Rev Genet. 2004:5:435-45.

99. Chistiakov DA, Hellemans B, Volckaert FAM. Microsatellites and their genomic distribution, evolution, function and applications: a review with special reference to fish genetics. Aquaculture. 2006;255:1-29.

100. Yano CF, Bertollo LAC, Liehr T, Troy WP, Cioffi MDB. W chromosome dynamics in Triportheus species (Characiformes, Triportheidae): an ongoing process narrated by repetitive sequences. J Hered. 2016;107:342-8.

101. Oliveira EA, Sember A, Bertollo LAC, Yano CF, Ezaz T, Moreira-Filho O, et al. Tracking the evolutionary pathway of sex chromosomes among fishes: characterizing the unique XX/XY1Y2 system in Hoplias malabaricus (Teleostei, Characiformes). Chromosoma. 2018;127:115-28.

102. Cioffi MB, Kejnovsky E, Bertollo LAC. The chromosomal distribution of microsatellite repeats in the genome of the wolf fish Hoplias malabaricus, focusing on the sex chromosomes. Cytogenet Genome Res. 2011;132:289-96.

103. Xu D, Lou B, Bertollo LAC, Cioffi MDB. Chromosomal mapping of microsatellite repeats in the rock bream fish Oplegnathus fasciatus, with emphasis of their distribution in the neo-Y chromosome. Mol Cytogenet. 2013;6:12.

104. Terencio ML, Schneider CH, Gross MC, Vicari MR, Farias IP, Passos KB, et al. Evolutionary dynamics of repetitive DNA in Semaprochilodus (Characiformes, Prochilodontidae): a fish model for sex chromosome differentiation. Sex Dev. 2013;7:325-33.

105. Yano CF, Poltronieri J, Bertollo LAC, Artoni RF, Liehr T, Cioffi MDB. Chromosomal mapping of repetitive DNAs in Triportheus trifurcatus (Characidae, Characiformes): insights into the differentiation of the Z and W chromosomes. PLoS One. 2014;9:e90946.

106. Oliveira EA, Bertollo LAC, Yano CF, Liehr T, Cioffi MDB. Comparative cytogenetics in the genus Hoplias (Characiformes, Erythrinidae) highlights contrasting karyotype evolution among congeneric species. Mol Cytogenet. 2015;8:56.

107. Pucci MB, Barbosa P, Nogaroto V, Almeida MC, Artoni RF, Scacchetti PC, et al. Chromosomal spreading of microsatellites and (TTAGGG)n sequences in the Characidium zebra and C. gomesi genomes (Characiformes: Crenuchidae). Cytogenet Genome Res. 2016;149:182-90. https://doi.org/10.1159/000447959.

108. Piscor D, Parise-Maltempi PP. Microsatellite organization in the $B$ chromosome and a chromosome complement in Astyanax (Characiformes, Characidae) species. Cytogenet Genome Res. 2016;148:44-51.

109. Bertollo LAC, Cioffi MB, Moreira-Filho O. Direct chromosome preparation from freshwater teleost fishes. In: Ozouf-Costaz C, Pisano E, Foresti F, Almeida Toledo LF, editors. Fish cytogenetic techniques. Enfield USA: CRC Press; 2015. p. 21-6. https://doi.org/10.1201/b18534-4.

110. Sumner AT. A simple technique for demonstrating centromeric heterochromatin. Exp Cell Res. 1972;75:304-6.

111. Pendás AM, Móran P, Freije JP, Garcia-Vásquez E. Chromosomal location and nucleotide sequence of two tandem repeats of the Atlantic salmon $5 \mathrm{~S}$ 
rDNA. Cytogenet Cell Genet. 1994;67:31-6. https://doi.org/10.1159/ 000133792.

112. Cioffi MB, Martins C, Centofante L, Jacobina U, Bertollo LAC. Chromosomal variability among allopatric populations of erythrinidae fish Hoplias malabaricus: mapping of three classes of repetitive DNAs. Cytogenet Genome Res. 2009;125:132-41.

113. Yano CF, Bertollo LAC, Cioffi MB. FISH-FISH: molecular cytogenetics in fish species. In: Liehr T, editor. Fluorescence in situ hybridization (FISH) application guide. 2nd ed. Berlin: Springer; 2017. p. 429-43.

114. Kubat Z, Hobza R, Vyskot B, Kejnovsky E. Microsatellite accumulation on the Y chromosome in Silene latifolia. Genome. 2008;51:350-6.

115. Levan A, Fredga K, Sandberg AA. Nomenclature for centromeric position on chromosomes. Hereditas. 1964;52:201-20.

Ready to submit your research? Choose BMC and benefit from:

- fast, convenient online submission

- thorough peer review by experienced researchers in your field

- rapid publication on acceptance

- support for research data, including large and complex data types

- gold Open Access which fosters wider collaboration and increased citations

- maximum visibility for your research: over $100 \mathrm{M}$ website views per year

At BMC, research is always in progress.

Learn more biomedcentral.com/submissions 